NBER WORKING PAPER SERIES

\title{
ENDOGENOUS DRINKING AGE LAWS \\ AND HIGHWAY MORTALITY RATES \\ OF YOUNG DRIVERS
}

Henry Saffer

Michael Grossman

Working Paper No. 1982

NATIONAL BUREAU OF ECONOMIC RESEARCH

1050 Massachusetts Avenue

Cambridge, MA 02138

July 1986

The research reported here is part of the NBER's research programs in Health Economics and Taxation. Any opinions expressed are those of the authors and not those of the National Bureau of Economic Research. 


\section{Endogenous Drinking Age Laws and Highway Mortality Rates of Young Drivers}

\section{ABSTRACT}

This paper presents estimates of the effects of the drinking age and beer taxes on youth motor vehicle mortality. The data set employed is a time serles, from 1975 to 1981 , of cross sections of the 48 contiguous states. Separate regressions for 15 to 17 year olds, 18 to 20 year olds and 21 to 24 year olds are presented. A simultaneous estimation model is used to account for the endogeneity of the drinking age. The results show that during the sample period an increase in the drinking age to 21 , which is approximately 8 percent, would have reduced mortality in the 18 to 20 year old group by approximately 14 percent. Also a 100 percent Increase in the real beer tax, which is approximately $\$ 1.50$ per case, would reduce highway mortality of 18 to 20 year olds by about 19 percent. This increase in the beer tax would also reduce mortality by about 8 percent for 15 to 17 year olds and by about 18 percent for the 21 to 24 year olds.

Henry Saffer

Department of Economics Kean College of New Jersey Union, NJ 07083
Michael Grossman Department of Economics City University of New York Graduate School 33 West 42nd Street New York, NY 10036 


\section{Endogenous Drinking Age Laws and Highway Mortality Rates of Young Drivers \\ Henry Saffer and Michael Grossman*}

\section{Int roduction}

In the past few years, there has been an Increased public awareness of the potentlally adverse effects of alcohol consumption. A major area of concern is alcohol related motor vehicle accidents. In an effort to control alcohol abuse, each 6tate has enacted a varlety of regulations governing the sale of alcohollc beverages. Recently, particular attention has been focused on the minfmum legal age for purchase and consumption of alcohol. In the early 1970's, these age minfmums were lowered in many states. Young drivers, however, tend to be more accldent prone than the general population. Concern that the 1ncreased avallabllity of alcohol might be exacerbating the already high accldent rate amoung young drivers led to the Federal Unfform Drinking Age Act of 1984. The Act denies a certaln percentage of Federal highway construction funds to states that fall to raise their minimum drinking age to 21 .

While raising the legal drinking age is an option to deal with alcohol abuse amoung young drivers, Increased taxation of alcohol is another policy that might achleve the same results. This polfcy tool, however has not been employed. Instead, Federal exclse taxes on beer and wine have been fixed, In nomfnal terms since November 1, 1951. The Federal exclse tax on distilled spirits was ralsed on october 1, 1985. State and local excise taxes have been Increased on occaston, but always to ralse revenue rather than to discourage consumption.

The purpose of this paper is to estimate the responstveness of youth 
motor vehicle fatality rates to increases in the legal drinking age and to variations in the cost of beer. The focus on young adults is important because motor vehicle accident mortality is the leading cause of death of persons under the age of 35, and the National Highway Traffic Safety Administration (1983) estimates that alcohol is involved in over half of these fatal accidents.

Research on the responsiveness of youth motor vehicle deaths to the to the cost of beer is Important because of proposals to Increase Federal exclse tax rates on all forms of alcoholic beverages. ${ }^{1}$ The tax rate on the alcohol in beer is only one third the tax rate of the alcohol in 1iquor. This has led to proposals to equalize tax rates by increasing beer taxes. Given the popularity of beer among young people and their poor driving records, it is important to obtain estimates of what effect higher beer taxes would have on motor vehicle fatality rates of young drivers. ${ }^{2}$

Estimates of the effect of Increased legal drinking ages on motor vehicle fatality rates of young drivers is also important because the Federa1 Uniform Minimum Drinking Age Act w111 explre at the end of fisca1 1988. The Insurance Institute for Highway Safety (1985) reports that Texas and Kansas have already adopted laws that will lower the legal drinking age as soon as the Federal penalties end.

There have been a variety of prior studies of the effects of alcohol regulation on motor vehicle accident rates of young drivers. Douglas (1983) provides an extensive review of this 1iterature. There have been few prior studies which estimate the effects of alcohol taxes or prices on highway fatalities. Cook (1981), however, estimates that states that raised their 
Ilquor tax rates had lower motor vehicle deaths of persons of all ages. Most studies of the legal drinking age conclude that increasing the legal drinking age would lower motor vehicle fatality rates of young drivers. For example, Wagenaar (1981), using time series data for the state of Michigan, finds a significant relationship between the drinking age and motor vehicle crashes. Wagenaar's methodology is 1deal for estimating short run effects In Michigan. Long run changes and changes in other states, however, cannot be Inferred from his study. A somewhat different conclusion is reached by Males(1986). Males concludes that increasing the drinking age only redistributes fatalities to older drivers. Most prior studies of the drinking age employ a univariate methodology. While the simplicity of a univariate methodology has certain advantages, the effect of variations in alcohol taxes and other variables is not controlled.

Three recent studies (McCornac 1982, Cook and Tauchen 1984, Saffer and Grossman 1986) of alcohol regulation and fatality rates of young drivers use multivariate estimation techniques. All three studies also use pooled time series of cross sections for the 48 contiguous states of the U.S. The study by McCornac uses data from 1970 through 1975 and focuses on the death rate of males aged 15 through 24. Data on highway conditions and liquor prices are also included with the drinking age. The study by cook and Tauchen uses data from 1970 through 1977 and focuses on the death rate of youths aged 18 through 20. Cook and Tauchen employ a set of time and state variables to control other factors influencing highway fatalities. The study by the present authors uses data from 1975 through 1981 and estimates separate fatality regressions for youths 15 to 17,18 to 20 and 21 to 24 . 
Data on beer taxes and highway conditions are included with the drinking age. Each study finds a negative relationship between fatalities and the drinking age. The latter study also finds a negative relationship between fatalities and beer taxes.

The research reported here differs from these three prior studies in a variety of ways. McCornac and Cook and Tauchen analyzed a period during which there was a downward trend in the legal drinking age. Between 1970 and 1975,29 states lowered thelr drinking ages. Both studies concluded that changes in the drinking age were exogenous to highway fatality rates of young drivers. Exogeneity of, the drinking age is not surprising since conformity with the voting age of 18 was the reason given for lowering the drinking age. This study employs a sample period in which 15 states raised their drinking ages. The reason clted for these increases is often concern over motor vehicle fatalities of young drivers. The drinking age should thus be treated as endogenous. This study differs from the earlier study by the present authors in that it employs a two equation simultaneous model to control for endogeneity of the drinking age.

\section{Analyt1cal Framework}

The empirical model is derived from a theoretical model consisting of a probability of fatality equation and a demand for alcohol equation. The probability of fatality is determined by alcohol consumption and a set of varlables measuring highway conditions and vehicle quality. It is assumed that, on average, alcohol consumption and driving under the influence of alcohol are positively correlated. The demand for alcohol is a function of prices,income and taste. The legal drinking age 1mposes difficulties or 
costs on underaged individuals who try to purchase alcohol. Therefore, as a measure of price, the legal drinking age is included in the demand for alcohol equation. In the probability of fatality equation, alcohol consumption is replaced by its determinants. This results in an equation with prices, the drinking age, income tastes, highway conditions and vehicle quality as determinants. This probability equation is aggregated over age groups in each state and is interpreted as a mortality rate equation.

Estimation of the mortality rate equation is hampered by potential endogeneity of the drinking age. This study uses data from 1975 to 1981 , a period when drinking ages were generally increasing. If these increases were motivated by mortality rates associated with the lowered drinking ages of the early 1970's, then the drinking age is endogenous. Endogeneity of the drinking age can be controlled with an econometric framework developed by Maddala (1983). Define the following variables: $S=$ an unobserved variable measuring sentiment against alcohol; $S^{*}=$ an unobserved variable measuring pressure to pass a 21 year old minimurn legal drinking age law; $D=$ the drinking age; $M=$ highway mortality rates for youths; $M *=$ highway mortality rates for youths when $D$ is not equal to 21 ; $x_{1}=$ a matrix of exogenous variables affecting $M ; X_{2}=a$ matrix of exogenous variables affecting S. The model can be written as:

$$
\begin{aligned}
& \text { (1) } M=x_{1} \beta_{1}+f_{1} D+g_{1} s+\mu_{1} \\
& \text { (2) } S=x_{2} \beta_{2}+\mu_{2}
\end{aligned}
$$

where $\beta_{1}, \beta_{2}, f_{1}, g_{1}$, are coefficients and $\mu_{1}$ and $\mu_{2}$ are error terms. Equation ( 1 ) assumes that mortality is a consequence of exogenous 
regressors $\left(X_{1}\right)$, the drinking age (D), and sentiment against alcohol (s). The sentiment variable (s), in equation (1), is necessary because such sentiment can have an independent effect on highway mortality rates. In states where sentiment is strongly against alcohol, youths may drink less and thus the state mortality rate may be lower than in states where alcohol is more acceptable. The effect of sentiment on mortality is independent of the drinking age. If states where sentiment is strongly against alcohol have higher drinking ages then exclusion of the sentiment variable will result in an overstatement of the effect of the drinking age. Sentiment is assumed to be a function of exogenous variables such as religion. This relationship is expressed by equation (2).

While sentiment against alcohol may be exogenous, pressure to pass a 21 year old drinking age, $S^{*}$, is not independent of youth mortality. Clearly, increased youth highway fatalities, which are believed to be assoclated with alcohol, increase pressure to pass a 21 year old drinking age. Exogenous sentiment, $S$, can also affect pressure to pass the 21 year old drinking age. These relationships are expressed as:

$$
\text { (3) } S^{*}=S+\theta M^{*}
$$

The drinking age, D, acts as an indicator of the unobserved variable $\mathrm{S}^{*}$. The relationship between $S^{*}$ and $D$ is defined as:

$$
\begin{aligned}
& \text { if } D=21 \text { then } \\
& \text { if } D=20 \text { then } \mathrm{S}_{3}>\mathrm{S}_{3}>\mathrm{c}_{2} \\
& \text { if } \mathrm{D}=19 \text { then } \mathrm{c}_{2} \geq \mathrm{S}^{*}>\mathrm{c}_{1} \text { and } \\
& \text { if } \mathrm{D}=18 \text { then } \mathrm{c}_{1} \geq \mathrm{S}^{*}
\end{aligned}
$$


the $c_{1}$ are unknown constants with $c_{3}>c_{2}>c_{1}$. The variable $M^{*}$ is the youth highway mortality rate when the drinking age 1s not 21 . The parameter $\theta$ is a welght. The variable $S$ has no weight because as an unobserved variable 1ts measurement scale 1s unknown.

To estimate the model, substitute equation (2) Into equation (1) which results in:

$$
\text { (4) } M=X_{1} \beta_{1}+X_{2} \beta_{2} g_{1}+f_{1} D+v_{1}
$$

and substitute equation (1) and (2) 1nto equation (3) to get

$$
\text { (5) } \mathrm{S}^{*}=\mathrm{X}_{1} \beta_{1} \theta+\mathrm{x}_{2} \beta_{2}\left(1+\mathrm{g}_{1} \theta\right)+\mathrm{v}_{2} \text {. }
$$

The dummy variable, D, does not appear in equation (5) because pressure to pass a 21 year old drinking age exists only if the drinking age 1s not 21 . The model can be estimated using a two stage procedure. ${ }^{3}$ The first step is the estimation of equation (5) by ordered probit with D replacing $S^{*}$. Four predicted probabilities result from this procedure. They are, respectively, the probabilities of an $18,19,20$ and 21 year old drinking age. A new variable $S^{* *}$ is defined as the sum of the four drinking ages welghted by their predicted probabilites. The variable $S^{* *}$ is the expected drinking age and is continuous with upper and lower values of 21 and 18 respectively. The second step is the estimation of equation (4) with $\mathrm{S}^{* *}$ replacing $D$. Since the mortality rate has a restricted range a logistic specification will conform to the data more closely than a 11near specification. The logistic specification is most easily achieved by transforming the mortality rate to $\ln (M / 1-M)$, where $\ln 1 s$ the natural logarithm. Maddala 
(1983) shows that welghted least squares should be used with this logistic transformation. The weight $1 \mathrm{~s}:[\mathrm{nM} /(1-\mathrm{M})]^{1 / 2}$, where $\mathrm{n}$ is the age specific population of the state.

The structural model defined by equation (4) and (5) has three 1mportant features. First, the exogenous variables are the same in equation (4) and (5). Second, the error terms $v_{1}$ and $v_{2}$ are correlated. Finally, the variable $D$ in equation (4) is endogenous.

Equation (4) and (5) are both 1dentified even though 1dentical exogenous variables are used in the two equations and $v_{1}$ and $v_{2}$ are correlated. Identification results from the use of $D$ in equation (4) and $S^{*}$ in equation (5). Under these conditions equation (4) can be distinguished from any Iinear combination of equations (4) and (5). Empirically estimation is possible because equation (5) is a nonlinear specification.

\section{Data}

The data set is a time series of state cross sections. The time period 1s 1975 through 1981 and the cross sections include the 48 contiguous states of the U.S. ${ }^{4}$ The values and summary definitions of all the vartables are show in table 1 .

The mortality rate was computed as motor vehicle deaths, by age and state, divided by population, by age and state. Motor vehicle deaths by age and state were provided by the National Highway Trafflc Safety Administration and come from unpublished data In the Fatal Accident Reporting System. ${ }^{5}$ Deaths pertain to state of occurrence rather than state of residence. Population data by age and state for 1980 were taken from the 1980 Census of Population (Bureau of the Census 1983) and for 1975 
from the Area Resource FIle (Applied Management Sciences 1980). Population data for the remaining years was derived from a logarithmic trend using the 1975 and 1980 data. ${ }^{6}$ The mortality rate was computed for all 15 to 17 year old victims, 18 to 20 year old victims and 21 to 24 year old victims. 7 The legal drinking age vartable is the minimum age for the purchase of beer with alcohol content of 3.2 percent or more. These data come from Wagenaar's (1981/1982) compilation of drinking age data. ${ }^{8}$ If a state raised its legal drinking age during the year, the drinking age is defined as the age in effect on January 1 of that year.

The beer tax is the sum of the Federal and state exclse tax rates on a case of 12 ounce containers of beer divided by the annual national Consumer Price Index (CPI). Deflation by the CPI is required to take account of trends in the prices of other goods between 1975 and 1981 . Each regression is estimated with time dummy variables to control trend in the price data and other data. The real beer tax is thus an accurate indicator of the relative price of beer provided the non-tax component of the relative price Is not state dependent.

The Federal exclse tax on a case of beer was fixed in nominal terms at 64 cents during the sample period. State exclse tax rates were obtained from the U.S. Brewers Assoctation (1984). If a state ratsed its tax during the year rather than on January 1 , its tax for the year is computed as a weighted average of the higher and lower rates. The weights are the fraction of the year that each rate was in effect.

The exogenous variables in the $\mathrm{X}_{1}$ matrix include a border age dumm variable. This variable is equal to one if a state has any bordering state 
with a lower drinking age. The border age variable is included because highway mortality for 18 to 20 year olds may increase as a consequence of interstate travel to purchase and consume beer. ${ }^{9}$

Real per capita personal income is also included in the $x_{1}$ matrix. This variable should be positively related to the demand for beer, to the quality and condition of motor vehicles, and to safe driving practices. The last relationship emerges because income and schooling levels are posttively related. In turn, more educated persons and their offspring are 11kely to be safer drivers. It follows that the predicted effect of income on the death rate is ambiguous. The Income data was published by the Bureau of Economic Analysis.

Three highway measures are included in the regressions. They are the number of vehicle miles traveled in $100,000^{\prime} s$ of miles per 1icensed driver, the number of 11 censed drivers aged 24 years or less as a fraction of the population aged 15 to 24 , and a dichotomous varfable that identffies states that require compulsory inspection of motor vehicles every year. 10 Stmilar variables have been used in interstate studies of the determinants of motor vehicle death rates of all age groups by Fuchs and Leveson (1967) and Peltzman (1975). The number of vehicle miles traveled per driver obviously reflects motor vehicle use and it is expected to have a positive regression coeffictent. In addition highway driving density probably rises as the number of vehicle miles traveled per driver rises. In general young drivers are more accident prone than older drivers, posstbly because the former group has a higher demand for risky driving (Peltzman 1975). Thus, an increase in the per capita number of young drivers should cause the 
death rate to increase. States with compulsory motor vehicle inspection programs are expected to have a lower death rate than other states because these programs should result in safer vehicles being operated by the driving public.

The number of licensed drivers of all ages, the number of licensed drivers aged 24 years or less, and the number of vehicle miles traveled were taken from the Federal Highway Administration. The Administration estimates vehicle miles of travel from data on gasoline consumption and motor vehicle registration by state. The compulsory inspection variable was obtalned from the Council of State Governments.

The variables in the $\mathrm{x}_{2}$ matrix are determinants of unobserved exogenous alcohol sentiment. For example, antialcohol sentiment should be relatively widespread in states in which religious groups that oppose the use of alcohol are prevalent. Antialcohol sentiment may also be high in states which a higher than average percentage of the population reside in dry counties. A dry county is one that prohibits the sale of alcoholic beverages.

The variables included in the $\mathrm{X}_{2}$ matrix are the percentage of the population who are Mormons, Southern Baptists, Catholics and Protestants (excluding Southern Baptists and Mormons). These variables for the years 1971 and 1980 were taken from surveys conducted by the National Council of Churches of Christ and the Glenmary Research Center. 11 Estimates for other years were computed by logarithmic trend. Also included in the $\mathrm{x}_{2}$ matrix is the percentage of state population that reside in dry counties. These data were obtained from the Distilled Spirits Council of the United States. 
IV. Results

Column 1 of 2 contains the results for a single equation mortality model for 18 to 20 year olds. Column 2 and 3 of table 2 contain the results for a simultaneous equation mortality model for 18 to 20 year olds. The single equation mortality model assumes that the drinking age is exogenous. This model provides an alternative to the simultaneous model and, by comparison, 1llustrates the endogenelty blas. The single equation model is estimated using welghted least squares and a logistic transformation of the dependent variable.

The estimation results for the single equation mortality model generally conform to the a priori expectations. The real beer tax and the drinking age are negative and significant as expected. The border age dummy Is positive and significant. This suggests that for contiguous states, differences in drinking ages Increase youth mortality rates. The Income effect Is negative suggesting that higher income individuals, or their offspring, are safer drivers and operate motor vehicles that are in better phystcal condition. An Increase in vehtcle miles traveled per licensed driver is found to rafse mortality. States that require inspection of motor vehicles are found to have lower mortality than other states. Finally the alcohol sentiment variables all have the expected $s 1 g n$ and all are significant with the exception of the Southern Baptist variable.

The estimation results for the simultaneous equation models are also presented In table 2. Column (2) contalns the results for the mortality equation and column (3) contains the results for the drinking age equation. The two equation model is necessary to control reverse causality 
In the drinking age. The empirical verification of this causality assumption is found in the coefficlent $\theta$, which was described above. The value of $\theta$ cannot be directly estinated as a regression coefficent but can be estimated by the ratio of the real beer tax coefficent from the drinking age. equation divided by the same coeffictent from the mortality equation. The value of $\theta$ is estimated as 8.636. The varlance of $\theta$ was estimated using the change of variable technique and the $t$ value is $6.18 .^{12}$ The empirical evidence thus supports the endogenelty assumption and the need for a two equation econometric model. 13

The coefficlents in the single equation model are biased because of correlation of the drinking age with the error term. A comparison of column (1) and column (2) In table (2) 1llustrates the effect of endogeneity bias. The drinking age coefflclent remains negative and significant In the simultaneous model, but the coeffictents increase in absolute value. The endogenelty problem also results in bias in the exogenous vartable coefficlents. Column 2 of table (2) shows that the beer tax remains negative and significant but increases in absolute value. The border age variable and Catholic variables become Insignificant when simultanelty is controlled. The Southern Baptist variable is Insignificant in both the single equation and simultaneous equation specifications. The coefficlents of the highway variables, Income, and the exogenous alcohol sentiment vartables are somewhat larger in the simultaneous model than in the single equation model.

The results for the drinking age equation are presented in column (3) of table 2. This equation can be interpreted as measuring the pressure to 
pass a 21 year old drinking age. The tax, border age, income and highway variables are all included in this equation as indirect measures of mortality. These variables should have the same sign in the drinking age equation as they have in the mortality equation because mortality has a positive causal influence on the pressure to increase the drinking age. The tax, border age and income variable are all significant and, as expected, have the same sign in the drinking age equation as they have in the mortality equation. None of the highway variables is significant. The Catholic and Protestant variables are the only exogenous sentiment variables that are significant. The sign of the Catholic and Protestant variables would be positive if these groups exert political pressure to Increase the drinking age. The sign of these variables would be negative if these groups exert pressure on young people not to drink and drive. Since the Catholic and Protestant variables are negative the latter effect must dominate.

Column 4 and 5 of table 2 contain, respectively, the results for simultaneous mortality models for 15 to 17 year olds and 21 to 24 year olds. Both models are specified exactly as the 18 to 20 year old mortality model, with the exception of the dependent variable. The drinking age could affect mortality of 15 to 17 year olds. The probability that an underaged individual can purchase alcohol may increase as the individual approaches the legal drinking age. If underaged individuals who have purchased alcohol, then drive drunk, the drinking age would affect mortality of the 15 to 17 year olds. Since the drinking age is insignificant In the 15 to 17 year old mortality equation, there is no support for this 
hypothesis. The drinking age could effect the mortality of 21 to 24 year olds If, as argued by Males (1986), higher drinking ages redistribute fatalities to older age groups. Again the drinking age is insignificant and thus offers no support for this hypothesis. The border age vartable 1s Insignificant in both the younger and older age group equations. This result is not surprising since no state allows those under 18 years old to purchase alcohol nor prohibits those over 21 years old from purchasing alcohol. The real beer tax is negative and significant for both age groups. For the younger group, this result may be the consequence of 111 gal purchases or that members of this group may be with older friends in fatal car accidents. The results for the remaining variables are simflar to the results in the 18 to 20 year old mortality equation.

\section{v. Conclusions}

The purpose of this paper was to estimate the effects of the drinking age and beer taxes on youth motor vehtcle mortality. The drinking age is assumed to be endogenous in the methodology used to compute these estimates. The econometric results show that mortality has a significant causal effect on the drinking age and that Ignoring the problem of endogeneity results in underestimation of the effects of this pollcy variable.

The final problem to be considered is estimating the effects that exogenous shifts in the two policy variables, the drinking age and the beer tax, wll have on youth motor vehicle mortality. The coeffictents and means values from the 18 to 20 year old mortality equation can be used to compute elasticities. The elasticity is defined as: $E=B(1-M) \bar{x}$. The elasticity of mortality with respect to the drinking age is 1.78 and the elasticity 
with respect to the real beer tax 1s .19 . An increase in the drinking age to 21 , which 1 s approximately 8 percent on average, would reduce mortality In the 18 to 20 year old group by approximately 14 percent. Also a 100 percent 1ncrease in the real beer tax (approximately $\$ 1.50$ per 24 unft case) would reduce highway mortality of 18 to 20 year olds by about 19 percent. This increase in the beer tax would reduce mortality by about 8 percent for the 15 to 17 year olds and by about 18 percent for the 21 to 24 year olds. In summary, the econometric results show that the drinking age and beer tax both have a significant influence on youth motor vehicle mortality. 
Table 1

Defintions and Means of Variablesa

\begin{tabular}{|c|c|}
\hline Variable & Defindtion, Mean, and Standard Deviation \\
\hline Notor vehicle death rate & $\begin{array}{l}\text { Deaths due to motor vehicle accidents per } \\
100,000 \text { population for tlie following three } \\
\text { age groups: } \\
\text { Ages } 15-17 \text {; mean=31.581. } \\
\text { Ages } 18-20 \text {, mean=51.468. } \\
\text { Ages } 21-24 \text {, mean=41.921. }\end{array}$ \\
\hline Keal beer tax & $\begin{array}{l}\text { Sum of Federal and state exclse taxes on a } \\
\text { case of } 24-t w e l v e \text { ounce cans of beer divided } \\
\text { by Consumer Price Index, 1967=1, mean=.518. }\end{array}$ \\
\hline Drinkinf age & $\begin{array}{l}\text { Minimum legal age in years for the purchase } \\
\text { and consumption of beer, alcoholic content } \\
\text { more than } 3.2 \text { percent, mean=19.404. }\end{array}$ \\
\hline Border age & $\begin{array}{l}\text { Dichotomous variable that equals one if a } \\
\text { state is a bordering state with a lower } \\
\text { drinking age. Mean }=.55 \text {. }\end{array}$ \\
\hline $\begin{array}{l}\text { Real per capita personal } \\
\text { income }\end{array}$ & $\begin{array}{l}\text { Yoney per capita personal income divided } \\
\text { by Consuner Price Index, } 1967=1 \text {, expressed } \\
\text { in ten thousands of dollars, mean=.3830, }\end{array}$ \\
\hline Velicle miles rraveled & $\begin{array}{l}\text { Vehicle miles traveled in hundred thousands } \\
\text { of intles per licensed driver, mean=.110. }\end{array}$ \\
\hline Young drivers & $\begin{array}{l}\text { Number of licensed drivers aged } 24 \text { or less } \\
\text { as a fraction of the populacton ared } 15-24 \text {, } \\
\text { mean }=.726 \text {. }\end{array}$ \\
\hline Inspection of motor vehicles & $\begin{array}{l}\text { Dichotomous variable that equals one if } \\
\text { inspection of motor vehicles is requited } \\
\text { every year, mean=.548. }\end{array}$ \\
\hline Normon & $\begin{array}{l}\text { Fraction of population who are lourinons, } \\
\text { mean=.012. }\end{array}$ \\
\hline Southern Baptist & $\begin{array}{l}\text { Fraction of population who are Soutiern } \\
\text { Baptists, mean=.074. }\end{array}$ \\
\hline Catholic & $\begin{array}{l}\text { Fraction of population who are Catholics, } \\
\text { mean=.210. }\end{array}$ \\
\hline Protestant & $\begin{array}{l}\text { Fraction of populatlon who are Protestants } \\
\text { (excludes Sourhern Baptists and Hormons), } \\
\text { mean=.199. }\end{array}$ \\
\hline Residents of dry counties & $\begin{array}{l}\text { Fraction of the population who reside in } \\
\text { dry counties (counties that prohibit the } \\
\text { sale of alcoholdc beverages), thean }=.033 .\end{array}$ \\
\hline
\end{tabular}

a Data pertain to the 48 contiguous states of the U.S. for the years 1975 through 1981. Heans of the death rates are weighted by the age-spectelc number of persons in the carcgoty at issue by state and year. Means of all other variables are weighted by the number of persons ayed 15-24 by state and year. 
Table 2

Estimated Coefficients ${ }^{\mathrm{a}}$

\begin{tabular}{|c|c|c|c|c|c|}
\hline & $\begin{array}{l}18-20 \\
\text { Mortal1ty } \\
\quad(1)\end{array}$ & $\begin{array}{l}18-20 \\
\text { Mortality } \\
\text { (2) }\end{array}$ & $\begin{array}{l}\text { Drinking } \\
\text { Age } \\
\text { (3) }\end{array}$ & $\begin{array}{c}15-17 \\
\text { Mortality } \\
\text { (4) }\end{array}$ & $\begin{array}{c}21-24 \\
\text { Mortality } \\
\text { (5) }\end{array}$ \\
\hline Real Beer Tax & $\begin{array}{l}-.339 \\
(6.35)\end{array}$ & $\begin{array}{l}-.374 \\
(5.39)\end{array}$ & $\begin{array}{r}-3.230 \\
(3.89)\end{array}$ & $\begin{array}{c}-1.62 \\
(13.15)\end{array}$ & $\begin{array}{l}-.341 \\
(4.73)\end{array}$ \\
\hline Drinking Age & $\begin{array}{l}-.060 \\
(4.68)\end{array}$ & $\begin{array}{l}-.092 \\
(2.13)\end{array}$ & - & $\begin{array}{l}.014 \\
(.43)\end{array}$ & $\begin{array}{r}-.026 \\
(.58)\end{array}$ \\
\hline Border Age & $\begin{array}{c}.089 \\
(2.51)\end{array}$ & $\begin{array}{l}.141 \\
(1.53)\end{array}$ & $\begin{array}{l}3.061 \\
(11.89)\end{array}$ & $\begin{array}{r}-.003 \\
(.05)\end{array}$ & $\begin{array}{l}.080 \\
(.84)\end{array}$ \\
\hline $\begin{array}{l}\text { Real Per Cap1ta Personal } \\
\text { Income }\end{array}$ & $\begin{array}{l}-2.270 \\
(6.40)\end{array}$ & $\begin{array}{r}-2.292 \\
(5.66)\end{array}$ & $\begin{array}{r}-10.909 \\
(4.00)\end{array}$ & $\begin{array}{r}-2.673 \\
(8.87)\end{array}$ & $\begin{array}{l}-2.806 \\
(6.66)\end{array}$ \\
\hline Vehicle Miles Traveled & $\begin{array}{c}9.191 \\
(11.54)\end{array}$ & $\begin{array}{c}9.268 \\
(11.56)\end{array}$ & $\begin{array}{r}-1.457 \\
(.262)\end{array}$ & $\begin{array}{l}9.149 \\
(15 \cdot 34)\end{array}$ & $\begin{array}{c}9.257 \\
(11.09)\end{array}$ \\
\hline Young Drivers & $\begin{array}{l}1.202 \\
(10.02)\end{array}$ & $\begin{array}{l}1.204 \\
(10.59)\end{array}$ & $\begin{array}{l}-.442 \\
(.378)\end{array}$ & $\begin{array}{l}1.299 \\
(15.38)\end{array}$ & $\begin{array}{l}1.297 \\
(10.97)\end{array}$ \\
\hline Inspection of Motor Vehicles & $\begin{array}{l}-.039 \\
(1.85)\end{array}$ & $\begin{array}{l}-.048 \\
(2.27)\end{array}$ & $\begin{array}{l}-.033 \\
(1.68)\end{array}$ & $\begin{array}{l}-.043 \\
(2.73)\end{array}$ & $\begin{array}{l}-.051 \\
(2.35)\end{array}$ \\
\hline Mormon & $\begin{array}{l}-.517 \\
(2.82)\end{array}$ & $\begin{array}{l}-.436 \\
(2.35)\end{array}$ & $\begin{array}{l}-1.918 \\
(1.263)\end{array}$ & $\begin{array}{l}-.382 \\
(2.78)\end{array}$ & $\begin{array}{l}-.760 \\
(3.95)\end{array}$ \\
\hline Southern Baptist & $\begin{array}{r}-.209 \\
(.97)\end{array}$ & $\begin{array}{r}-.104 \\
(.47)\end{array}$ & $\begin{array}{l}-.923 \\
(.483)\end{array}$ & $\begin{array}{r}-.065 \\
(.40)\end{array}$ & $\begin{array}{r}-.083 \\
(.36)\end{array}$ \\
\hline Catholic & $\begin{array}{l}-.221 \\
(1.81)\end{array}$ & $\begin{array}{l}-.225 \\
(1.46)\end{array}$ & $\begin{array}{l}-4.348 \\
(3.141)\end{array}$ & $\begin{array}{r}-.184 \\
(1.61)\end{array}$ & $\begin{array}{l}-.334 \\
(2.09)\end{array}$ \\
\hline Protestant & $\begin{array}{l}-.489 \\
(3.59)\end{array}$ & $\begin{array}{l}-.416 \\
(2.89)\end{array}$ & $\begin{array}{l}-1.906 \\
(2.004)\end{array}$ & $\begin{array}{l}-.288 \\
(2.68)\end{array}$ & $\begin{array}{l}-.874 \\
(5.82)\end{array}$ \\
\hline Residents of Dry Countries & $\begin{array}{l}-.592 \\
(4.02)\end{array}$ & $\begin{array}{l}-.589 \\
(3.95)\end{array}$ & $\begin{array}{l}-2.157 \\
(1.308)\end{array}$ & $\begin{array}{l}-.568 \\
(5.13)\end{array}$ & $\begin{array}{l}-.855 \\
(5.52)\end{array}$ \\
\hline$R-$ squared $^{b}$ & .62 & .62 & .46 & .71 & .63 \\
\hline
\end{tabular}

aThe t-values are in parentheses. Each equation also includes an Intercept and dichotomous variables for the years 1975 through 1980 .

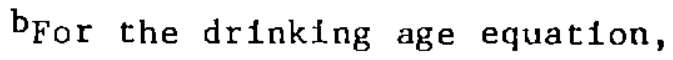

$$
\mathrm{R}^{2}=1-\frac{\log \mathrm{L}(\mathrm{A})}{\log \mathrm{L}(0)}
$$

where $\log L(A)$ equals the $\log 11$ kelihood function when maximlzed with respect to all the parameters and $\mathrm{L}(0)$ equals the $10 \mathrm{~g}$ l1kelihood function when maximlzed with respect to the intercept only. 


\section{Footnotes}

*Research for this paper was supported by Grant Number R01 AA05849 from the National Institute on Alcohol Abuse and Alcoholism to the National Bureau of Economic Research. We wish to thank the National Highway Safety Administration for providing us with motor vehicle deaths by age, year and state. We also wish to thank Frank Chaloupka for research assistance. This paper has not been submitted for approval by the NBER Board of Directors.

${ }^{1}$ For example see Moore and Gerstein (1981), Luks (1983), Cooke (1984), Harris (1984), Becker (1985) and Jacobson and Albion (1985).

${ }^{2}$ Grossman, Coate and Arluck (1986) provide data which indicate that beer is the drink of cholce amoung youths who drink alcoholic beverages. This study also finds no evidence that youths substitute one alcoholic beverage for another in response to price changes. This finding is consistent with those of other studies of the demand for alcohollc beverages. These studies aré summerized by Ornstein (1980).

${ }^{3}$ The ordered probit estimation of equation (5) is consistent and efficlent. However, in equation (4), since $S^{\star \star}$ replaces $D$ the two step procedure is consistent but not efficient. Amemiya (1979) provides a method for computation of the correct covariance matrix. For notational convenience, let :

$$
\begin{aligned}
& \mathrm{X}=\left[\begin{array}{lll}
\mathrm{X}_{1} & \mathrm{X}_{2}
\end{array}\right] \quad \text { (unwe1ghted data) } \\
& \mathrm{L}=\left[\begin{array}{llll}
\mathrm{X}_{1} & \mathrm{X}_{2} & \mathrm{~S}^{*}
\end{array}\right] \quad \text { (we1ghted data) } \\
& \mathrm{A}_{1}=\left[\begin{array}{llll}
B_{1} & \beta_{2} g & \mathrm{f}_{1}
\end{array}\right] \\
& A_{2}=\left[\begin{array}{lll}
\beta_{1} & B_{2}(1+g \theta)
\end{array}\right]
\end{aligned}
$$




$$
\begin{aligned}
& \sigma_{1}^{2}=\text { estimates variance of } v_{1} \\
& \sigma_{2}^{2}=\text { estimated variance of } v_{2} \text { where } v_{2} \text { is computed as (S** - D) } \\
& \sigma_{12}=\text { estimated covartance of } v_{1} \text { and } v_{2} \\
& v_{0}=\text { estimated covartance of } A_{2} \text { then, } \\
& \hat{\sigma}_{A l}^{2}=\left(\sigma_{1}^{2}-2 f \sigma_{12}\right)\left(L^{\prime} L\right)^{-1}+ \\
& \quad\left(f^{2}\right)\left(\sigma_{2}^{2}\right)\left(L^{\prime} L\right)^{-1}\left[X_{0} X^{\prime}\right] L\left(L^{\prime} L\right)^{-1} .
\end{aligned}
$$

Estimation of equation (4) and (5) provides a consistent estimates of $f$ and data to compute $\sigma_{1}^{2}, \sigma_{2}^{2}$, and $\sigma_{12}$

${ }^{4} \mathrm{Alaska}$ and Hawalt were omftted from the data set because several tmportant vartables were missing for these two states. The District of Columbia was omftted because tt is 1tkely that many of tts motor vehtcle accidents Involve nonrestdents.

${ }^{5}$ The Fatal Accldent Reporting System is described in detall in NHTSA (1983). Note that NHTSA tabulates alcohol related motor vehtcle fatalities. These data were not used because the tdentiffcation of alcohol related crashes is made by the pollce based on methods that vary from state to state.

${ }^{6}$ Population estimates for years other than 1980 were adjusted so that the age speciflc sum for every year colncided with the U.S. total reported by the Bureau of the Census (1982).

${ }^{7}$ Prior studies of the effect of changes tn the drinking age have used a varlety of mortality measures. These 1nclude: (1) nighttime fatal accidents Involving youthful drivers; (2) nighttime single vehtcle fatal accidents tnvolving youthful drivers; (3) nighttime slngle vehicle fatal accidents 
Involving youthful male drivers. Cook and Tauchen point out that these measures are only remotely indicative of total soctal costs. For this reason the mortality measure chosen includes all fatalities regardless of time of day or number of vehtcles.

${ }^{8}$ The legal age for the purchase of beer is very highly correlated with legal age for the purchase of liquor or wine. It 1s, therefore, not possible to use more than one drinking age variable in the same regression.

${ }^{9}$ Since fatalities are recorded by state of occurrence, this vartable will have a positive correlation with mortality if border crossing youths are kflled in thelr own state.

${ }^{10}$ The number of licensed drtvers for the years 1976, 1978, and 1980 was obtalned by averaging the number of drivers in the preceding and following years .

11 Jews are included with non-church members in the omitted category because the size of the Jewish population was not reported in the 1971 survey and was significantly underestimated in the 1980 survey.

12 The value of $\theta$ can be estimated using any pair of $x_{1}$ coeffictents from equations (4) and (5). However the only $x_{1}$ coefflclents that are signif1cant in both equations (4) and (5) are for the tax and 1ncome. The income coefficients also resulted in positive and significant estimates of $\theta$. To compute the variance of $\theta$ let $h_{1}=$ the real beer tax coefficent in the drinking age equation and $h_{2}=$ the real beer tax coefficient in the mortality equation. The vartable $\theta$ is then $h_{1} / h_{2}$. The variance of $\theta$ is defined by a Taylor series expansion and is equal to $\operatorname{var}\left(\mathrm{h}_{1}\right) *\left|1 / \mathrm{h}_{2}\right|+$ $\operatorname{var}\left(h_{2}\right) *\left|h_{1} /\left(h_{2}\right)^{2}\right|$. The covartance of $h_{1}$ and $h_{2}$ is assumed to be zero. 
13 Endogeneity of the real beer tax is also possible. However, several vartations of a three equation model falled to generate any meaningful evidence of tax endogenelty. The main problem with these models was cross sectional identification of the tax equation. 
References

Amemiya, T. "The Estimation of a Simultaneous Equation Tobit Mode1." Internationa1 Economic Review, 20, No. 1, 1979.

Applied Management Sclences, Inc. "Bureau of Health Professions Area Resource File User Documentation and Technical Documentation." Springfield, Virginia: National Technical Information Service, December 1980 .

Becker, G. S. "Don't Ralse the Drink1ng Age, Raise Taxes." Business Week, November $25,1985$.

Bureau of the Census, U.S. Department of Commerce. 1980 Census of Population. Volume I: Characteristics of the Population. Chapter B: Genera1 Population Characteristics. Part 1: United States Summary. Washington, D.C.: U.S. Government Printing office, 1983.

Bureau of the Census, U.S. Department of Commerce. Preliminary Estimates of the Population of the United States by Age, Sex, and Race: 1970 to 1981. Current Population Reports, Series P-25, No. 917, Ju1y 1982. Bureau of Economic Analys1s, U.S. Department of Commerce. Survey of Current Business, various years.

Bureau of Labor Statist1cs, U.S. Department of Labor. Monthly Labor Review, various 1ssues.

Coate, D., and Grossman, M. "Effects of Alcohol1c Beverage Prices and Legal Drinking Ages on Youth Alcohol Use. National Bureau of Economic Research Work1ng Paper, No. 1852, March 1986. Cook, P. J. "Increasing the Federal Alcohol Exc1se Tax." In Toward the Prevention of Alcohol Problems: Government, Business, and Community 
Action, edited by D. R. Gerstein. Washington, D.C.: National Academy Press, 1984.

Cook, P. J., and Tauchen, G. "The Effects of Minfmum Drinking Age Leg1slation on Youthful Auto Fatalities, 1970-1977." Journal of Legal Studies, 13, No. I (January 1984).

Counc11 of State Governments. Book of the States. Lexington, Kentucky: Iron Works Pike, vartous years.

Distilled Spirits Council of the United States. Annual Statistical Review. Washington, D.C.: Distilled Spirits Counctl of the Untted States, various years.

Douglas R. L. "Youth, Alcohol, and Traffic Accidents Current Status," In Recent Developments in Alcoholism, edited by M. Galanter, New York: Plenum Press, 1983.

Federal Highway Admintstration, U.S. Department of Transportation. Highway Statistics. Washington, D.C.: U.S. Government Printing Office, vartous years.

Fuchs, V.R. and Leveson, I. "Motor Vehicle Mortality and Compulsory Inspection of Vehtcles." Journal of the American Medical Assoctation, 201 (August 1967).

Grossman, M.; Coate, D.; and Arluck, G. M. "Price Sensitivity of Alcoholic Beverages in the United States." In Control Issues in Alcohol Abuse Prevention: Strategles for Communtties, edited by H. D. Holder. Greenwich, Connecticut: JAI Press, Inc., 1986. Harris, J. E. "More Data on Tax Pollcy." In Toward the Prevention of Alcohol Problems: Government, Business, and Communtty Action, edited 
by D. R. Gerstein. Washington, D.C.: National Academy Press, 1984. Insurance Institute for Highway Safety. The Highway Loss Reduction Status Report, 20, No. 9 (August 10, 1985). Jacobson, M., and Albion, M. "Raising Alcohol Taxes Is the Way to Cut Drinking and the Debt." Washington Post, August 11, 1985. Johnson, D. W.; Picard, P. R.; and Quinn, B. Churches and Church Membership in the United States, 1971. Washington, D.C.: Glenmary Research Center, 1974.

Luks, A. Will America Sober Up? Boston: Beacon Press, 1983. Maddala, G. S. Limited-Dependent and Qualitative Variables in Econometrics. Cambridge, England: Cambridge University Press, 1983. Males, M. A. "The Minimum Purchase Age for Alcohol and Young-Driver Fatal Crashes: A Long-Term View." Journal of Legal Studies, 15, No. 1, 1986. McCornac, D.C. "The Effects of Government Regulation on Teenage Motor Vehicle Mortality." National Bureau of Economic Research Working Paper No. 1030 , November 1982.

Moore, M. H., and Gerstein, D. R., editors. Alcohol and Public Policy; Beyond the Shadow of Prohibition. Washington, D.C.: National Academy Press, 1981 .

National Highway Traffic Safety Administration, U.S. Department of Transportation. Fatal Accident Reporting System 1981. DOT HS 806251 , January 1983.

Ornstein, S. I. "Control of Alcohol Consumption Through Price Increases." Journal of Studies on Alcoho1, 41, No. 9 (1980).

Peltzman, S. "The Effects of Automobile Safety Regulations." Journal of 
Political Economy, 83, No. 4 (August 1975).

Quinn, B., et al. Churches and Church Membership in the United States, 1980. Atlanta, Georgia: Glenmary Research Center, 1982.

Saffer, H., and Grossman, M. "Beer Taxes, The Legal Drinking Age and Youth Motor Vehicle Fatalities." National Bureau of Economic Research Work1ng Paper, No. 1914, May 1986.

U.S. Brewers Association. Brewers Almanac. Washington, D.C.: U.S. Brewers Association, 1984.

Wagenaar, A. C. "Legal Minfmum Drinking Age Changes in the Unfted States: 1970-1981." Alcohol Health and Research World (W1nter 1981/82). 